\title{
The Use of Police as Robbers for the Government and the Social Harm Resulting from That Use
}

\author{
Lawrence Southwick \\ Emeritus of Finance and Managerial Economics, University at Buffalo, Buffalo, USA \\ Email:1s5@buffalo.edu
}

How to cite this paper: Southwick, L. (2018) The Use of Police as Robbers for the Government and the Social Harm Resulting from That Use. iBusiness, 10, 41-50. https://doi.org/10.4236/ib.2018.102003

Received: March 8, 2018

Accepted: May 29, 2018

Published: June 1, 2018

Copyright $\odot 2018$ by author and Scientific Research Publishing Inc. This work is licensed under the Creative Commons Attribution International License (CC BY 4.0).

http://creativecommons.org/licenses/by/4.0/

\begin{abstract}
The object of this essay is to look at the use of civil asset forfeiture (CAF) in the US and to show how CAF acts to damage relations among income and racial groups in the US society. Prior papers by others have shown the ways that CAF is constitutionally suspect and have developed arguments for its injustice. I agree with those but want to add the adverse effect on society to the other problems that contraindicate its use. This paper is written to show what social problems are likely and argue that the price paid is too much for any benefits derived.
\end{abstract}

Keywords

Civil Asset Forfeiture, Income, Racial

The prior US Attorney General had imposed restrictions on civil asset forfeiture, with varying degrees of success, depending on state choices. However, the current US Attorney General has renewed the use of civil asset forfeiture by the federal government and, consequently for various other governments [1]. This is clearly unconstitutional government behavior despite what the Supreme Court has said. It is also a disaster for the belief by citizens that police are on their side.

Amendment 5 of the Constitution says that no person "shall be deprived of life, liberty, or property, without due process of law". Clearly, having the police take a person's property without any process other than an unsupported claim that the property has violated the law is not due process. (Amendment 4 is also on point.) It is also incredible that some governments appear to believe that property can violate the law without any human agency causing that violation. (Are these the same people who believe that guns cause murders without any 
human intervention? An example: A couple's assets were confiscated under the case name "State of Texas v. \$6037" see “Taken"[2]).

There are three types of asset forfeiture [3]. The first is criminal, where after arresting and convicting a law breaker, the assets used by that law breaker are subject to forfeiture by the court. Note that conviction and court ordered forfeiture are used as a remedy, penalty, or to recompense innocent parties harmed by the criminal. The second is administrative forfeiture. This is most often used when the possessor, whomever it may be, of the property is legally prohibited from that possession. For example, if it is illegal to possess a prohibited drug, that drug may be confiscated without a legal proceeding. Claims must be dealt with using a due process procedure, proving that the possessor had a legal right to possess the property in question. Neither of these is at issue in civil forfeiture. Having an asset be forfeited after being convicted of a crime where that forfeiture is a part of the law prior to time the crime was perpetrated is acceptable as due process.

Civil asset forfeiture is the third method. This is the method used that violates civil rights. Here is how civil asset forfeiture often works; the police stop someone on the highway on the pretext, typically specious, that the victim is a lawbreaker. They search for valuables in the car and pretend that these valuables (most likely money) are the result of some nefarious activity. The police then confiscate these valuables (arrest the valuables for committing a crime) and then release the occupants of the car without charging them with any crime. The assumption is explicitly that the cash confiscated or the car that is confiscated are simply paying for the crimes they have committed. The people who own the confiscated property are not charged with any crime and are released.

"In Volusia County, Florida, police stop motorists going south on I-95 and seize any cash they're carrying in excess of $\$ 100$ on suspicion that it's money to buy drugs." [4]. Since travellers' checks are much less likely to be used at present than they were a few years ago, people who do not have credit cards will typically need to use cash while travelling. The threat of confiscating this cash makes travelling more difficult. This practice thus interferes with the individual's right to travel across state lines. It is particularly hard on those who are less well-to-do.

In order to get their property returned after such confiscation, the owners have to employ lawyers and pay for the cost of suing that government that has confiscated the property. It will be necessary to prove the property to be innocent of the alleged crime in order to get it returned. How can anyone prove a negative, particularly of an inanimate object?

At the end of that process, it is still unclear that the victim will receive the property back. For poorer people, it is likely to be nearly impossible for them to get back property that has been forfeited by this process. They cannot afford to pay for the legal costs involved in proving that their property is innocent. Keep in mind that they have to pay the legal costs whether or not they win the case; only in unusual cases are they recompensed for their costs.

People who may be more affluent may have the wherewithal to fight through 
the process but still may be reluctant to spend the time and energy and the expenses if the amount is sufficiently small. This is a major bias against the innocent victim and in favor of the robbers (police).

The police who are making decisions about whose and which property to seize are, no doubt, cognizant of the above effects. They would prefer to take lesser amounts of cash and property that would not be contested in court due to the costs of court being too high for the amount of property seized. After all, why seize property or cash that will, with a relatively high probability, have to be returned? Of course, the costs of defending the decision to forfeit the assets are borne by the taxpayers. These costs are then typically covered from the victims' assets. We can assume that these property seizers are rational in their behavior.

It also follows that those police who have effectively become robbers [5]. They will also decide to pick on those who might have a potentially higher expectation of being robbed because of their minority status or youthfulness. These people will be less likely to pursue legal remedies than will more affluent persons.

Another point is that more affluent people are more likely to use credit cards than are poorer people who are less likely to have credit cards. This also results in poorer people and minorities being more likely to have cash available to be stolen by the police.

It is worth repeating that the person demanding in court to have his or her property restored will have to bear the costs for that demand. This includes any evidence needed to prove ownership as well as costs for legal counsel, travel, etc. The travel cost and time involved for the victim may well be excessive, particularly if the person is from out of state. It seems likely that the judicial system may well be viewed as stacked against the plaintiff and, in fact, it may actually be stacked that way. (It may be that speed traps are also more likely to result in fines for out-of-staters than for the locals).

"Once a federal prosecutor determines that there is civil forfeiture authority for the crime in question, the government is not required either to seek an indictment or obtain a criminal conviction before commencing a civil forfeiture action." [2]. Further, "in a civil forfeiture case, property is subject to forfeiture even if its owner is acquitted of or never called to defend against criminal charges". Id. Does that really look like due process?

Prosecutors are notoriously hostile to defendants. They are extremely likely to have a general bias against defendants and their property. It would appear very probable that a prosecutor would determine that any property that the police had seized was forfeitable. After all, why would the police have forfeited the property if it were inappropriate? Looking at it another way; when does a prosecutor not want to prosecute somebody or something?

The victim in these cases has no civil right to representation because it is defined as a civil case; he or she must pay for their own lawyer [6]. The burden of proof for property seizure is only "probable cause", id. There is a "presumption of guilt and a victim must prove innocence. Id. That is a very difficult challenge.

Now, the police who are trying to take a person's property certainly know all 
of this. Therefore, they will choose victims so as to maximize their net take. Poor or minority persons are very likely to be chosen. Of course, potential victims are well advised to avoid having sufficient property at hand to make its confiscation worthwhile to the confiscators. This means that poor or minority people should have less cash on hand if they make trips in the US. Poor people and minorities will thus be less likely to travel because of the expected costs of such possible forfeitures. If having cash is a crime, what is cash money worth? Clearly, it is worth less to people who may have it stolen from them.

I was told a story, supposedly done by a regional newspaper, about the police activities along the I-95 highway along the East Coast of the US. The drug runners are believed to use the northbound lanes to take their wares to the drug markets in the northeast while those who carry the proceeds of the sales back south use the southbound lanes. The major police interdiction efforts apparently are on the southbound lanes, not the northbound lanes. This clearly indicates that the police are not really attempting to interdict drug shipments; they simply want to steal the proceeds from the sales of the drugs. For a glimpse of this, see the January 15, 1989 story in the Orlando Sentinel [7].

In an earlier asset forfeiture case in Oct. 1992, Donald Scott, the owner of a ranch in Ventura County, CA, was killed by a sheriffs deputy when Mr. Scott exited his bedroom in response to a break-in of his home by 31 members of a multi-agency task force. They were hoping to be able to forfeit his ranch (worth in excess of $\$ 5$ million) due to drugs therein. After killing him, no drugs were found. Of course, the police said that because he was holding a 0.38 revolver over his head the killing was justified. (It needs to be noted that he had eye surgery the prior day and was in no condition to seriously threaten his attackers; he also was awakened by the break-in by Sheriff Spencer's deputies armed in SWAT Team gear).

Michael Bradbury [8], the District Attorney of Ventura County, after conducting an investigation, determined that asset forfeiture was a motive for the raid. The CA Attorney General, Dan Lundgren, criticized the report and Sheriff Spencer sued Bradbury. Bradbury was found to have acted correctly and the Sheriff was ordered to pay $\$ 50,000$ for Bradbury's legal bills. The County and federal government ultimately settled with the estate for $\$ 5$ million.

There are many other stories of innocent people victimized by the police through the asset forfeiture process. One such story was written by Casey Harper of the Daily Caller [9]. This gave 7 examples of such asset forfeitures. On the better side of this, at least a few of the victims were able to get their assets back, after court action. However, they had to go through much travail and bear substantial personal costs to get their possessions returned.

Christopher Ingraham reported in Nov. 23, 2015, in The Washington Post, that Law Enforcement personnel took more property from citizens using asset forfeiture in 2014 than burglars did in the US the same year. In that year, burglars stole $\$ 3.5$ billion while Treasury and Justice Departments in the US government deposited more than $\$ 4$ billion from asset forfeiture. Note that this does 
not include the property seized by state and local governments.

I would suggest that burglary, however, is not the appropriate comparison metric. Burglary is generally not intended by its perpetrators to be a violent crime. Burglary is defined, according to the Legal Information institute at Cornell University, as "the unlawful entry of a building at night with the intent to commit a felony therein." Robbery is generally the actual method used by police in asset forfeiture. Using the same source for the definition, "Robbery is the unlawful taking of property from the person of another through the use of threat or force." Clearly, the police act so as to force the victim to give up his property with the threat of force. After all, the police doing this are usually armed with firearms clearly displayed. That is explicitly a threat of force. If the victim does not stop and give up his property, he may well fear that the firearm will be used against him.

Now, let us consider how much property is taken in robberies committed by non-police. In 2014, the FBI reported that there were 325,802 robberies in the US with an average value of cash and property taken of $\$ 1227$ per robbery. Multiplying this out yields $\$ 400,000,000$ taken by robbers [10]. The amount taken by police in their official government robberies amounted to more than $\$ 4$ billion as given above. That is, official robbers (police) took more than 10 times much as all other robbers. (This does not even include asset forfeitures by state and local police.) That means that the victims are ten times as likely to be robbed by police as by non-police.

States received some \$657 million in "equitable sharing payments" in 2013. That happens even in states that do not allow civil asset forfeiture. It is allowed by federal laws that permit such sharing [11]. This equitable sharing is simply a payoff between federal government and local or state policing agencies.

All the states have some form of civil asset forfeiture. The main difference among them is in the use of the funds so acquired. Official uses in 39 states and D.C. include: for forfeiture expenses, allowed in 41 states and D.C., 15 states use those funds for liens and debts. 31 states use forfeited funds for law enforcement purposes. 23 states pay these funds directly to law enforcement agencies. 9 states pay such funds to non-law enforcement agencies. 10 states pay their general funds. Finally, 14 states use the funds for treatment and education, (presumably, some anti-drug.) Of course, inasmuch as money is fungible, the forfeited funds can be substituted for funds raised in proper ways. The purported uses can in practice be anything the state or local government wants [12].

Certainly, it is possible that at least some of those from whom money or property is confiscated are criminals of some sort. However, there are at least three problems with that seeming fact. First, there is no conclusive evidence of criminal activity on the part of the typical victim. If there were, criminal forfeiture could be used. Second, there has been no judicial adjudication of any criminal activity. Third, any connection between any person's purported criminal activity and that person's penalty is absent. This would imply that two people who actually committed the same crime would have penalties that bear no relation to 
each other. This would seem to be a violation of Amendment 14 by "denying persons the equal protection of the laws". Note that eighty percent of the victims were never charged with a crime [12].

If one recalls the history of Prohibition, it may be remembered that alcohol smugglers tended to prey on one another, stealing the prohibited alcoholic beverages or the money received by the sellers. This is much like that; one bootlegger steals that which has already been illegally acquired by another. Alternatively, a person who has sold illicit merchandise has that merchant losing to another the proceeds of the sale.

In at least one case, a person who sold a house, taking back a mortgage, to another person who then used the house for prostitution lost his claim to the house; the government took the house and refused to recognize the claim [4]. The owner of a motel was stripped of his ownership (later overturned in court) on the unsupported claim that it was used for drug use.

Another crime alleged is money laundering. Supposedly, some crime has been committed and the proceeds of that crime have been received by the seller. Drugs would be the typical high cash crime. If some person is stopped by police and found to be carrying cash, it well may be confiscated under the spurious allegation that they are money laundering. Keep in mind that no evidence of actual criminality is actually presented in court for any of the assets forfeited. The money can only be retrieved by proving its innocence.

It may be alleged that there is a scent of a drug on the money. Given the prevalence of illegal drugs in the society, a drug sniffing dog may be used to make the connection. However, that drug sniffing dog may alert to drugs even though the person carrying the cash is not actually involved in any drug money laundering, simply through the social prevalence of airborne particles on the drugs.

Consider the following; A drug sniffing dog indicates that a wad of cash has been around some drugs. Now, the police feel justified in confiscating that cash. How can the victim prove that he has no ties to drugs? The confiscation is almost impossible to prove invalid. Having the owner of the cash be required to prove his innocence (or his cash's innocence) turns around all our standard jurisprudence.

Now, let us look at the impact of this forfeiture on the way the police are viewed. In one case, a black couple was stopped by the police and their cash was taken by the police. Their child was in the car at the time. The mother asks the rhetorical question, "How can I explain this to my son?" Their cash was not a major amount (although it may have been major to the victims), but the impact will be felt by that boy for a long time. He will, accurately, believe that the police are not there to help him. He will probably grow up with the feeling that the police are there to steal from him. Will he have any respect for the police? Any respect will be tempered by the apprehension of what they may take from him. What about his friends and acquaintances? When he tells the true tale of the stolen assets, those told about it will have their perceptions of police adversely affected by that story. 
The "Black Lives Matter" perception that police are not on their side can only be exacerbated by each such asset forfeiture inflicted on innocent black people. This outcome does not appear to be considered by those involved in this practice. After all, any police murders resulting from the attitude of the killers and thus from the police criminal behavior toward the minorities and consequently inducing those murders is not actually directed at those individual police who did the robberies. However, all of the police are likely to have been tainted by those police who are taking the property in a civil forfeiture. The result then is that all police are likely to be considered by the victims as robbers.

The "Black Lives Matter" people argue that police are more inclined to kill non-white people during arrests than they do others who are white. This is refuted by statistical evidence. However, the taint of bias will remain for all police when some are forfeiting private assets. This is necessarily the case when police are acting in such a high-handed way with minority and poorer victims.

Makowski et al. [8] find that in fact, it appears that minorities and other non-whites are targeted for asset forfeiture.

Another concern that does not appear anywhere to be considered is the psychological effect on police who are asked to do this forfeiture. Police, while they are ostensibly asked to do an easy task which is to rob travellers of their money or other valuables, are in effect asked to act as robbers on behalf of a criminal government. This has to have an adverse effect on persons who, presumably, start out having a certain level of morality. That morality has to be eroded during their assignment to act as robbers. It can be further expected that this job will reduce their feelings of self-worth. As they watch some of their superiors use the stolen funds for their own benefit, (example: Tulsa, Oklahoma, cops drive a Cadillac Escalade stencilled with the words “this used to be a drug dealer's car, now it's ours?' [2]. They will feel that they have been dirtied by their superiors for their superiors' own benefit.

As a consequence, why wouldn't we expect the police who are doing these robberies to think that they should get some benefit themselves? Any time we have a prohibition of some commodity, there is a tendency for police themselves to become corrupted. As one possibility, suppose the police stop someone who has a couple of thousand dollars in cash. Now, instead of confiscating that cash, why not make an offer by the arresting officer to let him keep half while taking the other half for themselves? I'd bet that a lot of the victims would take that offer! (Especially if they were facing the high odds of losing it all.) [13]

The trend of taking the property of poorer, minority people through the asset forfeiture program will certainly further divide the people of the US. Poorer people will feel, correctly, that they are threatened by the agents for the rich who wish to steal from them. This antipathy will accrue to all police rather than just those who are actually physically robbing them. That is a major externality affecting all public safety, not just those who are taking advantage of this legalized robbery. The Florida Highway assigned a special detail of 16 felony officers to patrol I-95. In addition, a Georgia Highway Patrol spokesman, where they have 
been accused of discriminating against Floridians denied that, stating, "We don't look for Florida plates." [7]. Those with license plates from further away have a higher cost of returning to fight the forfeiture than do locals. (This is why speed traps targeting non-locals are preferred by those setting them up.)

The policing groups who use this robbery tactic frequently use as their excuse that their budgets are too tight. They say that they would be unable to afford the equipment and personnel to fight crime if they were forced to actually use due process for the asset forfeitures to get the needed funds. I would suggest that perhaps the people voting to fund such departments and actions would certainly not like it if the same forfeiture techniques were applied to them. If the public doesn't want to provide the funds for the police, then the police should be honest and get along with those funds that are provided for them. It is certainly not a valid excuse that they want more money and have to steal it. Any robber or thief could make that excuse in an equally valid manner for any money they steal. Kelly \& Kole find little effect of asset forfeiture revenues on effective policing [14].

Baicker and Jacobson [15] found that federal and state governments that authorize local police to keep a substantial proportion of assets forfeited have as one result that counties reduce appropriations to those police agencies so as to essentially capture the forfeitures for themselves. We can fairly say that such counties are in fact participating in the robberies that the police then commit.

Williams [16] points out that the "War on Drugs" has been a failure insofar as usage of illicit drugs. She then suggests that "Thus, there must be some reason besides inertia for the continuation of an unsuccessful war. One justification could lie in the success of civil forfeiture, allowing supplements to law enforcement revenues in the midst of inadequate budgets and contributing to "collaborative efforts" between federal and state agencies. Where would these budgets and "collaborative efforts" be if civil forfeiture were eliminated? This could explain why the "war on drugs" has continued for so many years despite ample evidence that it is a failure." This is much like Prohibition (of alcoholic beverages) that resulted in police corruption and little if any reduction in alcohol consumption but a substantial increase in murder and other crime during the 1920s and early 1930s.

Now, let's look at the reasons leading to the adverse social consequences of civil asset forfeiture. An innocent person or family is stopped along a highway and robbed by the police of their money or other possessions. Whenever they are able to return home, you should think about the friends and neighbors that they will tell of their misadventure. Of course, the place where this has occurred and the state will figure prominently in the tale. Some may be incredulous but, when others have the same tale of being robbed by some state's police, two and two will get put together. Whole groups of people of the same ethnicity will realize that they are being targeted because of their skin color and/or their economic class. This will reduce their satisfaction with the US as well as with the police. Further, if they do not see people of other ethnicities being treated as badly at the 
same time, they will recognize the discrimination against them.

The group "Black Lives Matter" contends that police are more prone to killing people with a dark skin color. I doubt that, and there is a lack of evidence for it as expressed, but it seems that there is really a discriminatory attitude and discrimination in the actual application of civil asset forfeiture. If they complain about that discrimination, it will not do to deny it since it is apparently actually true. The denial will add dishonesty to the criminal behavior of the asset forfeiters.

Over a period of time, the numbers of innocent people swept up in this asset forfeiture using police to get more funds will accumulate. Thus, when an accusation of discriminatory behavior in robbing people for government gain is made, there will be an increasing number of people who can attest to the truth of the accusation. This needs to be stopped everywhere in the US Make the accusation untrue; don't just deny it. A lack of candor will reduce the credibility of any statement by the police.

It will be argued, of course, that stopping this activity will allow the truly guilty to avoid the consequences of their crimes. That is certainly true, but the social cost of punishing the innocent is really much greater for our country. Blackstone's quotation that "It is better that ten guilty persons escape than that one innocent suffer". Commentaries on the Laws of England, is relevant in this regard. Actually, it may be that the current rules regarding asset forfeiture result is punishing many more innocents than guilty persons. (See above on the amounts raised.)

Inasmuch as the actual bearers of illicit cash or goods can be expected to understand the risks of being stopped and searched, they will have an incentive to act so as to reduce that risk. If they use alternative roads, alternative hiding places for cash, more care not to violate in any way local traffic laws, and other techniques, they can reduce their chances of being stopped in ways which innocent people may not think necessary. The result is that a larger and, over time, increasing percentage of those who are stopped and have their property taken by the police robbers will be innocent than the percentage of those who have actually committed the alleged crimes.

The divisiveness of civil asset forfeiture will certainly reduce the willingness of citizens to accept police actions and their belief in the value of police activities. That may be revealed in the rejection of police testimony during trials resulting in guilty persons being acquitted in unrelated matters. There may be more hung juries. Police work will be more difficult and criminals will be more difficult to bring to justice. That suggests higher costs of policing as well as lower effectiveness of the police which at least will partially offset any gains from civil asset forfeiture.

The major concern I have in this issue is the wedge it inserts between the country's more affluent citizens and other citizens. The monetary benefit to the government agencies certainly does not outweigh the aggregate of social costs 
and direct costs to the victims of the police robberies.

\section{References}

[1] Horwitz, S. (2017) Sessions on Asset Forfeiture. Washington Post. https://doi.org/10.1177/073401680202700207

[2] Stillman, S. (2013) Taken. New York.

[3] Gaumer, C. (2007) Assistant United States Attorney Southern District of Iowa. United States Attorneys' Bulletin, 59-63.

[4] Pilon, R. and Burrus, T. (2015) Ending Legalized Piracy: Civil Asset Forfeiture Reform. Policy Priorities for the 114 th Congress.

[5] Rothschild, D. and Block, W.E. (2016) Don't Steal; the Government Hates Competition: The Problem with Civil Asset Forfeiture. The Journal of Private Enterprise, 31, 45-56. https://ssrn.com/abstract=2959039

[6] Heritage Foundation (2015) Arresting Your Property.

[7] Vosburgh, M. and Sentinel, O. (1989) I-95: Drug Pipeline for Eastern U.S.

[8] Makowsky, M.D. and Stratmann, T. and Tabarrok, A.T. (2017) To Serve and Collect: The Fiscal and Racial Determinants of Law Enforcement. GMU Working Paper in Economics No. 16-17. https://ssrn.com/abstract=2745000

[9] The 7 Most Egregious Examples of Civil Asset Forfeiture. Casey Harper.

[10] 2014 Crime in the United States, FBI. "Robbery Overview”.

[11] Snead, J. (2014) Civil Asset Forfeiture: 7 Things You Should Know. Heritage Foundation.

[12] Williams, M.R., Holcomb, J.E., Kovandale, T.V. and Bullock, S. (2010) Policing for Profit. Institute for Justice.

[13] Engle, E. (2012) Libertarianism and Resistance to Civil Asset Forfeiture to the State. International Journal of Public Law and Policy, 287-298. https://ssrn.com/abstract=1899311

[14] Kelly, B.D. and Kole, M. (2013) The Effects of Asset Forfeiture on Policing: A Panel Approach. Forthcoming in Economic Inquiry. https://ssrn.com/abstract=2335161

[15] Baicker, K. and Jacobson, M. (2004) Finders Keepers: Forfeiture Laws, Policing Incentives, and Local Budgets. National Bureau of Economic Research, Working Paper 10484 .

[16] Williams, M.R. (2002) Civil Asset Forfeiture: Where Does the Money Go? Criminal Justice Review, 27, 321-329. 